\title{
Zrównoważony rozwój jako podstawa polskiej polityki ekologicznej - w poszukiwaniu nowej formuły kompromisu ekologii z ekonomią
}

Polityka ekologiczna kształtowała się w Polsce na przestrzeni ostatnich lat w zmieniającym się otoczeniu ustrojowym, prawnym, gospodarczym i finansowym ${ }^{1}$. Dokonujące się przemiany wywierały wpływ na sposób podejścia do ochrony środowiska, do systemu prawa ochrony środowiska ${ }^{2}$ i polityki ekologicznej3. J.Śleszyński zwraca uwagę na to, że ekonomiczne instrumenty polskiej polityki ochrony środowiska oparte są o ukształtowaną w latach siedemdziesiątych ubiegłego stulecia zasadę sprawcy i odpowiedzialności powszechnej

Przemiany polityczno-ustrojowe i społeczno-gospodarcze w Polsce, na przełomie lat osiemdziesiątych i dziewięćdziesiątych XX wieku, stały się asumptem do sformułowania nowego podejścia do polityki ekologicznej. Było to zgodne z nurtem przemian gospodarczych i społecznych dokonujących się w całym regionie $^{5} .10$ maja 1991 roku Sejm RP podjąl uchwałę aprobującą przyjętą rok wcześniej przez Radę Ministrów Politykę Ekologiczną Państwa ${ }^{6}$. Sformułowana

Należy pamiętać przy tym o dorobku prawnym II Rzeczpospolitej Polskiej w zakresie prawa ochrony środowiska i kształtowania postaw proekologicznych w ówczesnym społeczeństwie i wśród przedsiębiorców, a także o toczącej się wówczas żywej dyskusji o kierunkach rozwoju polskiej ekologii. Zob. na ten temat np. A.Wodziczko, Ochrona przyrody wczoraj, dziś i jutro, Ochrona Przyrody, Nr 16/1936. Również zaraz po II wojnie światowej kwestie ochrony środowiska naturalnego znalazły swoich znamienitych propagatorów, chociażby w osobie W.Szafera. Zob. szerzej na ten temat: W. RADECKI, Samorzad terytorialny i ochrona środowiska. Przepisy $z$ komentarzem, Warszawa 1991, s.13 in.

2 Zob. szerzej L. GaRdjan-Kawa, Administrowanie zasobami środowiska po reformie ustrojowej, Warszawa 2000, s.13 in.

Zob. szerzej M.Podolak, Polityka ekologiczna Polski w okresie transformacji, Lublin 2004, s.37 i n.

4 Zob. J.Śleszyński, Polityka ochrony środowiska w Polsce, [w:] Międzynarodowe zarządzanie środowiskiem..., M.Kramer..., s..271 in.

5 Zob. T. Żylicz, Z. LeHoczki, Towards Environmental Recovery. The Czech Republic-HungaryPoland-Slovakia, [w:] Changes in the Regional Economy in the Period of System Transformation, R. Domański, E. Judge, Warszawa 1994. 
wówczas polityka ekologiczna, nazwana później Pierwszą Polityką Ekologiczną Państwa (dalej także w skrócie: I PEP), stała się nie tylko deklaracją polityczną, ale również podstawą ustrojową dla programowania i realizacji przez administrację publiczną działań na rzecz ochrony środowiska. W roku 2000 przez Sejm została przyjęta Druga Polityka Ekologiczna Państwa (II PEP)7. Następnie w roku 2002 przez Radę Ministrów została opracowana Polityka ekologiczna państwa na lata 2003-2006 z uwzględnieniem perspektywy na lata 2007-2010. Miała ona juź ściśle określony charakter prawny, wskazany w ustawie z dnia 27 kwietnia 2001 roku Prawo ochrony środowiska ${ }^{9}$ (dalej także w skrócie: u.p.o.ś. ${ }^{10}$. Zgodnie z przepisami tej ustawy polityka ekologiczna państwa ma na celu stworzenie warunków niezbędnych do realizacji ochrony środowiska ${ }^{11}$, określając w szczególności: cele ekologiczne, priorytety ekologiczne, rodzaj i harmonogram działań proekologicznych, środki niezbędne do osiągnięcia celów, w tym mechanizmy prawno-ekonomiczne i środki finansowe. Politykę ekologiczną państwa przyjmuje się na 4 lata, z tym że przewidziane w niej działania w perspektywie obejmują kolejne 4 lata ${ }^{12}$. Politykę ekologiczną państwa uchwala Sejm na wniosek Rady Ministrów ${ }^{13}$.

6 Zob. Uchwała Sejmu RP z dnia 10 maja 1991 roku w sprawie polityki ekologicznej państwa (Monitor Polski z 1991 r., Nr 18, poz. 118).

7 W literaturze przedmiotu zwraca się uwagę na fakt, że II PEP została przyjęta przez Radę Ministrów dnia 13 czerwca 2000 r., a następnie dnia 22 sierpnia 2001 r. uchwalona przez Sejm. Artykuł 10 ust. 2 ustawy z dnia 27 lipca 2001 r. o wprowadzeniu ustawy Prawo ochrony środowiska, ustawy o odpadach oraz o zmianie niektórych ustaw (Dz.U. z 2001 r. Nr 100, poz.1085), nakazywał opracowanie nowej polityki ekologicznej, wyznaczając na to termin do 31 grudnia 2002 roku. Tymczasem II PEP uchwalona została jeszcze przed wejściem w życie ustawy $z$ dnia 27 kwietnia 2001 roku Prawo ochrony środowiska (Dz.U.z 2001 r., Nr 62, poz.627 z późn.zm.). Zastanowienia wymaga więc, jak zauważa M.Bar, czy II PEP była w pełni zgodna z wymogami wspomnianej ustawy. M.Bar zwraca uwagę na fakt, że II PEP obejmuje lata 2000 - 2025, gdy tymczasem zgodnie $z$ art. 14 ust. 2 ustawy Prawo ochrony środowiska politykę ekologiczną przyjmuje się na 4 lata, $z$ tym, że przewidziane w niej działania w perspektywie obejmują kolejne 4 lata; zob. M.Bar, J.Boć, M.Bojarski, M.Górski, J.Jendrośka (red.) J.Jerzmański, E.KaletaJagiełło, A.Lipiński, K.Nowicki, J.Rotko, W.Skarżyńska, T.Tatomir, Ustawa Prawo ochrony środowiska. Komentarz, Wrocław, $2001 \mathrm{r}$. Na temat charakteru prawnego polityki ekologicznej zobacz także: E. Radziszewski, Prawo ochrony środowiska. Przepisy i komentarz, Warszawa 2003.

8 Zob. Uchwała Sejmu RP z dnia 8 maja 2003 r. w sprawie przyjęcia Polityki Ekologicznej Państwa na lata 2003-2006 z uwzględnieniem perspektywy na lata 2007-2010 (MP z 2003 r., Nr 33, poz.433). Wcześniej, w dniu 17 grudnia 2002 roku, dokument ten przyjęła Rada Ministrów.

9 Ustawa Z dnia 27 kwietnia 2001 r. Prawo ochrony środowiska (Dz.U.z 2001 r. Nr 62, poz.627 z pózn.zm.).

10 Zob. na temat prawnego charakteru polityki ekologicznej państwa: J.Jendrośka (red.), Ustawa Prawo ochrony środowiska. Komentarz, Wrocław 2001

11 Art.13 u.p.o.ś.

12 Art.14 u.p.o.ś.

13 Art.16 u.p.o.ś. 
Organ wykonawczy województwa, powiatu i gminy, w celu realizacji polityki ekologicznej państwa, sporządza odpowiednio wojewódzkie, powiatowe i gminne programy ochrony środowiska. Programy, o których mowa, uchwala odpowiednio sejmik województwa, rada powiatu albo rada gminy ${ }^{14}$. W roku 2002 został także opracowany Program Wykonawczy do II Polityki Ekologicznej Państwa na lata 2002-2010 $0^{15}$, wskazujący konkretne działania oraz instrumenty służące realizacji celów wskazanych w II PEP.

Wymienione wyżej akty prawne oraz dokumenty oficjalne stanowią prawno-ustrojową oraz programową podstawę polityki ekologicznej obowiązującej w Polsce.

Wiodącą zasadą polskiej polityki ekologicznej jest przyjęta w Konstytucji $\mathrm{RP}^{16}$ (dalej także w skrócie: Konst.) zasada zrównoważonego rozwoju, która została sformułowana w 1987 roku w tzw. Raporcie Brundtlanda Światowej Komisji do spraw Ochrony Środowiska i Rozwoju (ang. UNCED) i uznana przez społeczność miedzynarodową za wzorzec rozwoju społeczno-gospodarczego i postępowania w sprawach dotyczących środowiska naturalnego - w roku 1992, na Konferencji Narodów Zjednoczonych w Rio de Janeiro ${ }^{17}$. Podstawowym założeniem zrównoważonego rozwoju jest taka realizacja polityki i działań w poszczególnych sektorach gospodarki i życia społecznego, która prowadzi do zachowania zasobów i walorów środowiska naturalnego w stanie zapewniającym trwałe, nie doznające uszczerbku, możliwości korzystania z nich, zarówno przez obecne jak i przyszłe pokolenia, przy jednoczesnym zachowaniu trwałości funkcjonowania procesów przyrodniczych ${ }^{18}$ oraz naturalnej różnorodności biologicznej ${ }^{19}$. Istotą zrównoważonego rozwoju jest równorzędne traktowanie racji społecznych, ekonomicznych i ekologicznych, co oznacza konieczność integrowania zagadnień ochrony środowiska z politykami w poszczególnych dziedzinach gospodarki ${ }^{20}$.

14 Na temat planowania i wdrażania polityki ochrony środowiska zob. także: B. KRIKKE, W. Zaworska-Matuga, Planowanie i wdrazanie polityki ochrony środowiska. Poradnik, Warszawa 2002.

15 Zob. komunikat po posiedzeniu Rady Ministrów z dnia 17 grudnia 2002 r. (źródło: www.kpmr. gov.pl).

16 Art.5 Konst.

17 Na konferencji w Rio de Janeiro przyjęto także Globalny program dzialania na XXI wiek w zakresie środowiska naturalnego, w formie dokumentu pt. Agendy 21; zob. L.Möller, Znaczenie polityki ochrony środowiska z punktu widzenia przedsiębiorstw w aspekcie międzynarodowym, [w:] Międzynarodowe zarządzanie środowiskiem..., M.Kramer.., s. 217 i n. oraz Agenda 21. Progress Report 1992-1998. Ind Updated Edition, Warsaw 1998.

18 Zob. szerzej A. Przyborowska-Klimczak, Ochrona przyrody. Studium prawnomiędzynarodowe, Lublin 2004, s.25 in.

19 Por. P. Leroy, Political modernisation and the renewal of environmental policy arrangements, [w:] Sustainable development an european view, M.R.Dudzińska, A.Pawłowski, Lublin 2000, s.9 i n.

20 Zob. D. Maśniak, Ubezpieczenia ekologiczne, Kraków 2003, s.21 i n. 
Zasada ta powinna wywierać wpływ m.in. na strategię realizacji zadań publicznych związanych z ochroną środowiska i stanowić ważne wskazanie dla decydentów w sytuacji, gdy realizacja określonych, publicznych inwestycji proekologicznych (np. w dziedzinie zaopatrzenia w wodę pitną lub oczyszczania ścieków) może być zbyt kosztowna w odniesieniu do prognozowanych efektów ekologicznych. Chodzi tu chociażby o inwestycje na terenach rozproszonych i słabo zaludnionych, gdzie jednostkowe koszty inwestycyjne są dużo wyższe, a efekty ekologiczne znacząco mniejsze, niż na terenach o zwartej zabudowie i gęsto zaludnionych. Autor z niepokojem obserwuje nasilające się w ostatnich latach, przede wszystkim w Unii Europejskiej, a także w Polsce, zbyt rynkowe i gospodarcze podejście do realizacji zadań publicznych związanych z ochroną środowiska i traktowanie ich wręcz w kategoriach przedsięwzięć komercyjnych, co może prowadzić w dłuższej perspektywie do nierównego traktowania odbiorców usług proekologicznych. Nie chodzi w tym przypadku li tylko o samą kwestię realizacji inwestycji, ale także o znaczną dywersyfikację poziomu kosztów ponoszonych przez poszczególne grupy odbiorców proekologicznych usług publicznych. Przy podejmowaniu strategicznych decyzji o realizacji poszczególnych inwestycji należałoby większą uwagę przywiązywać do kwestii równoważenia racji ekonomicznych i społecznych, skłaniając się raczej ku mniejszemu rygoryzmowi w podejściu do efektów ekonomicznych i finansowych inwestycji, a większą wagę przypisując racjom społecznym i ekologicznym. Jest to na pewno trudne, w szczególności w Polsce, w okresie, gdy jednostki samorządu terytorialnego, tak jak cały sektor finansów publicznych, przeżywają problemy finansowe. Jednakże ekologia nie należy do wyborów łatwych. Można ją porównać do ochrony zdrowia, gdyż zarówno w ekologii, jak i też w ochronie zdrowia, należy mieć na uwadze to, że życie i zdrowie ludzkie, a także jakość życia ludzkiego, są kategoriami o statusie dobra najwyższej wartości, w stosunku do których nie można kierować się względami ekonomicznymi w takim stopniu, jak w odniesieniu do dóbr innej kategorii. W ocenie autora można przewidywać, że w niedalekiej przyszłości spór o charakter relacji ekonomicznych i środowiskowych w zakresie publicznych inwestycji proekologicznych, może się zaostrzyć. Konstatacja ta skłania ku poszukiwaniu nowej formuły kompromisu ekonomii z ekologią ${ }^{21}$.

Zasada zrównoważonego rozwoju uzupełniana jest szeregiem zasad pomocniczych, które odnoszą się do istotnych kwestii ekologicznych.

${ }_{21}$ Zob. na temat aktualnych problemów związanych $\mathrm{z}$ wdrażaniem koncepcji zrównoważonego rozwoju: S. KozŁowski, Aktualne problemy zrównoważonego rozwoju, [w:] Filozoficzne i społeczne uwarunkowania zrównowazonego rozwoju, A.Pawłowski (red.), Lublin 2003, s.99 i n. oraz Z.Sadowski, Dezyderat trwałego rozwoju i warunki jego spelnienia (tezy), [w:] Filozoficzne..., A.Pawłowski (red.)..., s. 13 i n. 
Zasada przezorności oznacza, że działania mające na celu rozwiązywanie pojawiających się problemów ekologicznych powinny być podejmowane już wtedy, gdy pojawia się uzasadnione prawdopodobieństwo, że dany problem wymaga rozwiązania, a nie dopiero wtedy, gdy pojawia się całkowite potwierdzenie tego faktu ${ }^{22}$. Zasada ta powinna być jednym $z$ ważnych wyznaczników działań inwestycyjnych w ochronie środowiska. Mając przykładowo świadomość negatywnego wpływu odpadów na środowisko naturalne i na zdrowie ludzkie, działania inwestycyjne w tym zakresie powinny być realizowane nawet mimo braku ostatecznych wyników badań lub przykładów uzasadniających ostatecznie ilościowe lub jakościowe, negatywne efekty oddziaływania poszczególnych kategorii odpadów. Zasada przezorności została wprowadzona do systemu pierwotnego europejskiego prawa wspólnotowego Jednolitym Aktem Europejskim z dnia 17 lutego 1986 r. (dalej takie w skrócie: JAE), który uzupełnił Traktat o Wspólnocie Europejskiej $^{23}$ (dalej takż w skrócie: TWE) o tytuł VII dotyczący ochrony środowiska ${ }^{24}$. W artykule $130 \mathrm{r}$ ust. 2 TWE wprowadzono wówczas zapis, który stanowi, że działaniu Wspólnoty w dziedzinie środowiska naturalnego opierają się na zasadzie działania zapobiegawczego, zasadzie naprawiania szkody w pierwszym rzędzie u źródła i na zasadzie „zanieczyszczający płaci”. Traktat o Unii Europejskiej $^{25}$ (dalej takze w skrócie: TUE) potwierdził znaczenie wspólnotowej polityki ochrony środowiska.

Istotna jest także zasada prewencji, która zakłada, że przeciwdziałanie negatywnym dla środowiska skutkom emisji zanieczyszczeń powinno być podejmowane na etapie planowania i realizacji danych przedsięwzięć. Przy wyborze środków zapobiegawczych oraz sposobów likwidacji skutków określonych procesów lub zdarzeń, preferencje powinny uzyskiwać m.in. następujące działania: (1) na rzecz przebudowy modelu produkcji i konsumpcji w kierunku zmniejszania presji na środowisko, w szczególności poprzez stosowanie tzw. najlepszych dostępnych technik ${ }^{26}$; (2) zintegrowane podejście do ograniczania i likwidacji zanieczyszczeń i zagrożeń, zgodne z zaleceniami Dyrektywy Rady WE nr 96/61/ WE w sprawie zintegrowanego zapobiegania zanieczyszczeniom i kontroli ${ }^{27}$; (3)

22 Por. J. Boć, K. Nowacki, E. SAmborska-Boć, Ochrona środowiska, Wroclaw 2004, s.147 i n.

23 Zob. Traktat $\mathrm{z}$ dnia 25 marca 1957 roku o ustanowieniu Wspólnoty Europejskiej (tekst jedn. O.J.C. 1997.340.173. z późn.zm.). W odniesieniu do ochrony środowiska zob. art. 2 oraz art. 174 in. TWE.

24 Zob. art. 25 JAE.

25 Zob. Traktat z dnia 7 lutego 1992 r. o Unii Europejskiej (tekst jedn. O.J.C. 1997.340.145.z późn. $\mathrm{zm}$.).

26 Zarówno w literaturze anglojęzycznej, jak i też polskojęzycznej, używany jest skrót BAT od angielskiej nazwy: Best Avalaible Technics, tzn. Najlepsze Dostępne Techniki.

${ }_{27}$ W literaturze przedmiotu dyrektywa ta jest często określana w skrócie jako dyrektywa IPPC (ang. Integrated Prevent Polutants and Control). 
wprowadzanie prośrodowiskowych systemów zarządzania procesami produkcji i usługami, zgodnie z ogólnoświatowymi i europejskimi wymaganiami w tym zakresie, wyrażonymi m.in. w standardach ISO $14000^{28}$ i $\mathrm{EMAS}^{29}$, programach czystszej produkcji oraz tzw. Responsible Care ${ }^{30}$.

Ważnym warunkiem skuteczności działań na rzecz zrównoważonego rozwoju jest stosowanie zasady równego dostępu do środowiska przyrodniczego, co jest niezwykle istotne z punktu widzenia strategii publicznych inwestycji proekologicznych. Stosowanie bowiem tej zasady powinno skłaniać ku równemu traktowaniu, już na etapie planowania inwestycyjnego, potencjalnych beneficjentów proekologicznych usług publicznych, bez względu na realia ekonomiczne, czy też finansowe.

W polityce gospodarczej i polityce ochrony środowiska bardzo ważna jest również zasada „zanieczyszczający płaci”. Oznacza ona nałożenie pełnej odpowiedzialności, w tym materialnej, za skutki zanieczyszczania i stwarzania innych zagrożeń dla środowiska, na ich sprawców. Zasada ta została opracowana i przyjęta przez OECD ${ }^{31}$ w 1972 roku i uznana przez Unię Europejską za zasadę prawną.

Stosowana w państwach wysoko rozwiniętych zasada pomocniczości, zawarta przeważnie w konstytucjach krajowych, oznacza, iż władze publiczne wyższego szczebla powinny podejmować działania wówczas, gdy władze publiczne niższego szczebla albo społeczności lokalne i organizacje pozarządowe nie są w stanie tych działań skutecznie zrealizować. Na poziomie Unii Europejskiej zasada ta, wynikająca z Traktatu o Wspólnocie Europejskiej stanowi, że Unia podejmuje działania nie należące do jej kompetencji wówczas, gdy cele proponowanych

${ }_{28}$ Zob. szerzej: A. Matuszak-Flejszman, Jak skutecznie wdrożyć system zarzadzania środowiskowego według normy ISO 14001, Poznań 2001; a także: Program promocji systemów zarzadzania środowiskowego w Polsce, mat. Ministerstwa Środowiska, Warszawa 2003; Wdrażanie systemów zarzqdzania środowiskowego w ramach wspólpracy dwustronnej z państwami Unii Europejskiej, mat. Ministerstwa Środowiska, Warszawa 2003.

${ }^{29}$ ISO - (ang.) International Standarisation Organization (Międzynarodowa Organizacja Normalizacyjna $-\mathrm{z}$ siedzibą w Genewie; seria norm ISO 1400 jest związana $\mathrm{z}$ ochroną środowiska); EMAS - (ang. Environmental Management and Audit Scheme - System Zarzqdzania $i$ Audytu Środowiskowego). W zakresie tłumaczenia zwrotów anglojęzycznych autor korzystał ze słowników: K. CzeKierda, Stownik ochrony środowiska i ochrony przyrody, english-polish, Białystok 1995 oraz K. CzEKIERDA, Stownik ochrony środowiska i ochrony przyrody, polish-english, Białystok 1995.

30 Responsible Care, czyli Odpowiedzialność i Troska, to ruch zainicjowany w 1984 roku w Kanadzie, którego celem jest podjęcie działań przemysłu chemicznego na świecie na rzecz ochrony środowiska. Do grona kilkudziesięciu państw, które przystąpily do tego programu, w 1992 roku dołączyła także Polska. Przyjęte zostały zasady przewodnie tego programu, w myśl których przedsiębiorstwa przemysłu chemicznego wzywane są do poprawy wszystkich aspektów swej działalności związanych z ochroną zdrowia, bezpieczeństwa i ochroną środowiska.

31 Organisation for Economic Co-operation and Development (Organizacja Wspołpracy Gospodarczej i Rozwoju) - zob. dalej. 
działań nie mogą być osiągnięte przez państwo członkowskie ${ }^{32}$. W polskiej polityce ekologicznej stosowanie tej zasady oznacza stopniowe przekazywanie przez administrację rządową części kompetencji i uprawnień decyzyjnych dotyczących ochrony środowiska administracji samorządowej. W odniesieniu do realizacji zadań publicznych $w$ dziedzinach takich, jak: zaopatrzenie w wodę pitną, odprowadzanie i oczyszczanie ścieków lub zbierania i składowanie odpadów, zasada ta skutkuje większą odpowiedzialnością władz lokalnych za poziom i jakość proekologicznych usług publicznych, a co za tym idzie również za stan lokalnego środowiska naturalnego, co powinno znajdować wyraz w bardziej efektywnej realizacji lokalnych inwestycji proekologicznych. $Z$ drugiej strony należy jednakże zauważyć ryzyko wystąpienia pewnych zagrożeń i negatywnych zjawisk związanych z przekazywaniem niektórych zadań na niższe szczeble. Chodzi przede wszystkim o zjawisko decentralizacji zadań bez jednoczesnego finansowego umocowania podmiotów, które przejmują dane zadania. Może to prowadzić nawet do osłabienia tempa inwestycyjnego lub nawet do zaniechania, z powodu braku środków finansowych, realizacji poszczególnych inwestycji proekologicznych. Dlatego też decentralizacji zadań w dziedzinie ochrony środowiska powinna towarzyszyć za każdym razem przemyślana i dobrze zaprojektowana reforma systemu finansów publicznych.

Zasada skuteczności ekologicznej i efektywności ekonomicznej ma zastosowanie do wyboru do realizacji określonych przedsięwzięć inwestycyjnych w ochronie środowiska, wymagających nakładów finansowych, a następnie, w trakcie i po zakończeniu ich realizacji, do oceny osiągniętych wyników. W praktyce oznacza ona dążenie do minimalizacji nakładów inwestycyjnych na jednostkę uzyskanego efektu. Jest to oczywiście pożądany model planowania i realizacji publicznych inwestycji proekologicznych, jednakże w praktyce trudny do osiągnięcia. Zasada ta nie powinna być traktowana, zdaniem autora, jako najważniejsza podstawa decyzji inwestycyjnych. Należy ją traktować jako istotną, ale nie jedyną, lecz uzupełniającą zasadę, w odniesieniu do zasady zrównoważonego rozwoju.

Zarówno zasada zrównoważonego rozwoju, jak i też inne wymienione wyżej zasady uwikłane są współcześnie w szereg dylematów, często o bardzo istotnym i głębokim wyrazie społecznym i gospodarczym.

32 Art. 5 TWE stanowi, że Wspólnota działa w granicach kompetencji powierzonych jej niniejszym Traktatem oraz celów w nim wyznaczonych. W dziedzinach, które nie należą do jej kompetencji wyłącznej, Wspólnota podejmuje działania, zgodnie z zasadą pomocniczości, tylko wówczas i tylko w takim zakresie, w jakim cele proponowanych działań nie mogą być osiągnięte w sposób wystarczający przez Państwa Członkowskie, natomiast z uwagi na rozmiary lub skutki proponowanych działań możliwe jest lepsze ich osiągnięcie na poziomie Wspólnoty. Działanie Wspólnoty nie wykracza poza to, co jest konieczne do osiągnięcia celów niniejszego Traktatu. 
Człowiek żyjący w XXI wieku staje bardzo często przed koniecznością dokonywania wyborów pomiędzy wartościami lub dobrami, kierując się rozumem, wiarą, doświadczeniem, opierając się o róźnorodne systemy światopoglądowe. Powinien jednak zadawać sobie pytanie o hierarchię wartości i dóbr oraz o wzajemne relacje pomiędzy nimi. Co jest ważniejsze: dobrobyt czy pokój, ochrona zdrowia czy edukacja, rozwój gospodarczy czy ochrona środowiska? Czy istnieją wartości absolutne, a jeżeli tak, to jakie: życie pojedynczego człowieka, czy rozwój całej społeczności?

Człowiek współczesny, zarówno w wymiarze indywidualnym, jak i też w wymiarze społecznym, jest uwikłany w różne dylematy i niestety na podstawie własnego wyboru pozbawiony jest komfortu opierania się o jeden system prawd i wartości uniwersalnych. Często skutkuje to m.in. trudnością w wypracowaniu w wielu sferach aktywności ludzkiej katalogu jednoznacznych i akceptowanych przez ogół reguł postępowania, wolnych od relatywizmu. Człowiek współczesny chętnie ucieka w świat nieprecyzyjnych pojęć i niejasnych sformułowań, dystansując się jednocześnie od brania odpowiedzialności za sprawy rudymentarne. Te zjawiska i procesy występują w sposób niezwykle wyraźny w relacjach człowiek - środowisko naturalne.

Na przestrzeni dziejów w różnorodny sposób kształtował się charakter tych relacji, począwszy od lęku człowieka pierwotnego przed żywiołami przyrodniczy$\mathrm{mi}$, poprzez fascynację pięknem środowiska naturalnego, do rabunkowej gospodarki zasobami naturalnymi i degradacji środowiska, ku zadumie nad potrzebą zrównoważonego rozwoju ${ }^{33}$. „Wspomniany człowiek poprawia również naturę, ingeruje w jej prawa i tajemnice, niszczy to co naturalne w środowisku naturalnym, ingeruje w przyrodę, często ją niszczy za cenę mylnie rozumianego rozwoju ludzkości" ${ }^{34}$. Sfera ta jest szczególnie dotknięta piętnem konieczności dokonywania nie rzadko trudnych wyborów pomiędzy dobrami ekonomicznymi, gospodarczymi, a ekologicznymi. Jest naznaczona potrzebą udzielania odpowiedzi na pytanie, jak dalece wartość życia i jakość zdrowia ludzkiego są wyznacznikami priorytetów programowania polityki zrównoważonego rozwoju oraz w jaki sposób wpływają na model zarządzania wykorzystaniem zasobów naturalnych i na system ochrony środowiska naturalnego.

W jakim kontekście można rozważać ekonomiczną wartość środowiska naturalnego i w jaki sposób ekonomiczna kategoryzacja środowiska naturalnego może odnosić się do pojmowania tego środowiska jako dobra wyższego rzędu, mającego bezpośredni wpływ na jakość życia ludzkiego, a zatem dobra wymyka-

33 Rozważając tego typu problemy warto sięgnąc do opracowania A. KaLinowsKiej, Ekologia wybór na nowe stulecie, Warszawa 2002.

34 S. KasprzaK, Normatywny wymiar ekologicznych i sozologicznych idei w systemie prawa państwowego i kościelnego, Lublin 2003, s. 34. 
jącego się niejako spod ocen li tylko ekonomicznych? ${ }^{35}$ Pojmowanie relacji człowiek - środowisko jest bardzo zróżnicowane w poszczególnych nurtach myśli filozoficznej i poglądów moralnych, w religiach i w prawno-ustrojowych koncepcjach organizacji państwa. Problematyka ta eksplorowana jest również na wielu polach naukowych w ramach różnorodnych dyscyplin nauk ekologicznych, takich jak: ekologia, sozologia, sozotechnika, sozoekonomia, etyka środowiskowa, bioetyka, ekofilozofia, ekoteologia, polityka ekologiczna ${ }^{36}$, jak i też w naukach prawnych, w szczególności w ramach prawa ochrony środowiska.

Na współczesne problemy środowiska naturalnego należy spojrzeć szeroko, poprzez pryzmat wielu zjawisk, procesów i zagadnień, zarówno ekonomicznych, finansowych, prawnych, administracyjnych, ustrojowych, technologicznych, jak i też filozoficznych i moralnych. W takim szerokim kontekście należy umiejscowić zagadnienia dotyczące pojmowania idei zrównoważonego rozwoju.

Punktem wyjścia do rozważań są kwestie z pogranicza filozofii, moralności, ekonomii, finansów i prawa, dotyczące racjonalnego gospodarowania zasobami naturalnymi, poprawy stanu środowiska naturalnego i jego ochrony oraz regulacji i kształtowania postaw i zachowań ludzi oraz podmiotów w odniesieniu do środowiska naturalnego, a także wyznaczania granic prawnych tych zachowań i sankcjonowania ich przekroczenia. Przede wszystkim należy zastanowić się nad istotą stosunku człowieka do środowiska naturalnego na początku XXI wieku. Jak zauważa Z. Hull „szeroko rozumiana i coraz częściej podnoszona problematyka ekofilozoficzna nabiera dzisiaj szczególnego znaczenia właśnie z racji społeczno-praktycznych: rozpoznanie aktualnego i określenie pożądanego stosunku człowieka (społeczeństwa) do środowiska przyrodniczego jest nie tylko poznawczo ale i egzystencjalnie ważne"37.

Człowiek wywiera ogromny wpływ na życie biologiczne na Ziemi i na jego otoczenie. Jest w stanie wywierać zarówno wpływ pozytywny, jak i też negatywny, przyczyniający się do degradacji otoczenia, w którym żyje. Moźliwość wywierania tak znaczącego wpływu na całą planetę powoduje, że interakcyjna aktywność człowieka powinna być rozważnie programowana. „Człowiek jest pierwszym gatunkiem biologicznym na Ziemi, który zdolny jest zmodyfikować powierzchnię całej planety, jej biosferę, atmosferę i klimat w sposób bardzo głęboki i global-

35 Zob. np. G. ANDERSON, J. ŚLEszyŃsKi (red.), Ekonomiczna wycena środowiska przyrodniczego, [w:] Wartościowanie dóbr i zasobów środowiska, Białystok 1996.

36 Zob. szerzej na temat nauk ekologicznych: J.M. DoŁĘGA, Z filozofii nauk ekologicznych, [w:] Ochrona srodowiska spoleczno-przyrodniczego w filozofii i teologii, (red.) J.M.Dołęga, J.Czartoszewski, A.Skowroński, Warszawa 2001, s. 25 i n. oraz S.Wrzosek, Zarzadzanie środowiskiem przez administracje publiczna w Polsce, Białystok 1999, s.18 in.

37 Z. Hull, $O$ dwóch sposobach pojmowania i uprawiania filozofii ekologii, [w:] Ochrona środowiska spoleczno-przyrodniczego..., (red.) J.M.Dołęga...,op. cit. s. 38. 
ny"38. Zrozumienie tej prawdy musi znaleźć się u podstaw rozważań będących przedmiotem niniejszej pracy. Jeżeli zgadzamy się, że najsilniejszym instynktem człowieka jest instynkt życia i wola przeżycia i jednocześnie przyjmujemy założenie, że człowiek powinien mieć świadomość skali i siły swojego oddziaływania na otaczający go świat i zarazem rozumieć, że egzystencja ludzka jest związana ze stanem środowiska naturalnego, to powinniśmy uznać racjonalność postępowania i pozytywną reakcję człowieka w odniesieniu do środowiska naturalnego za zachowanie pożądane.

Obok racjonalności, drugim kryterium zachowania człowieka powinna być, przy zachowaniu wolności wyboru, odpowiedzialność za własne życie, a także za życie społeczności globalnej, i to nie tylko odpowiedzialność za ochronę i utrzymanie życia, ale również w rozumieniu współczesnym - za jego odpowiednią jakość i właściwy standard. Odpowiedzialność nie jest niestety „popularną" cechą postępowania współczesnego człowieka. „Człowiek nie jest zadowolony z tego, że ciąży na nim tak duża odpowiedzialność, odpowiedzialność za losy całej ludzkości.[...] Proces cedowania odpowiedzialności na kogoś innego jest dość powszechnym zjawiskiem w kulturze zachodniej”39. A zatem, jeżeli człowiek ma szacunek do własnego życia i życia innych, to również ma podstawę do racjonalnego i odpowiedzialnego stosunku do środowiska naturalnego. Szacunek do życia jako podstawowej i najważniejszej wartości kształtuje szacunek do innych wartości i dóbr, w tym do otaczającej nas natury. Dlatego też w państwach o systemach autorytarnych i totalitarnych, zorganizowanych w sposób niedemokratyczny, których władza nie ma szacunku dla życia ludzkiego, przeważnie nie ma również warunków do dbałości o stan środowiska naturalnego. Chociaż oczywiście nie jest to żelazną regułą, gdyż niestety również w państwach demokratycznych obserwujemy często zjawisko instrumentalnego podejścia do korzystania z zasobów naturalnych i do ochrony środowiska, jednakże przeważnie powodowane to jest dokonywaniem świadomego wyboru określonych priorytetów polityki rozwoju społeczno-gospodarczego, a nie brakiem poszanowania dla życia ludzkiego.

Warunkami przetrwania gatunku ludzkiego jest m.in. przetrwanie przyrody i zachowanie bioróżnorodności. J.Życiński podkreśla, że „przyroda, która dla wielu generacji stanowiła dziedzinę dramatycznej walki o byt, ujawnia nam dziś ostrzej niż kiedykolwiek swe piękno [...] Tam, gdzie wcześniejsze generacje dostrzegały jedynie chaos nieskoordynowanych procesów, dla nas ujawnia się fascynująca rzeczywistość ukrytej głębi racjonalnych struktur"40. Jeżeli przyjmie-

38 E. Kośmicki, Problem odpowiedzialności czlowieka za ewolucję, [w:] Ochrona środowiska spoteczno-przyrodniczego..., (red.) J.M. DoŁĘGA...,op. cit. s. 55.

${ }^{39}$ A. Kuzıon, Wolność wyboru a problem odpowiedzialności - rozważania Ericha Fromma, [w:] Ochrona środowiska spoleczno-przyrodniczego..., (red.) J.M.Dolęga...,s. 294 i n.

40 J. ŻycIŃsKI, Ulaskawienie natury, Kraków 1992, s. 180. 
my racjonalność i odpowiedzialność za podstawę kształtowania się pozytywnych postaw człowieka względem otaczających go składników i elementów przyrody i zasobów naturalnych, to powinniśmy zastanowić się także nad innymi uwarunkowaniami tych postaw, tzn. w szczególności nad uwarunkowaniami społeczny$\mathrm{mi}$, technologicznymi, gospodarczymi, finansowymi i prawnymi.

W sensie społecznym, środowisko naturalne rozumiane jako dobro, nie powinno być postrzegane jako własność jednostek, ale powinno być traktowane jako dobro wspólne stanowiące „funkcję tych wszystkich warunków, które zapewniają ludziom w społeczeństwie życie godne człowieka" ${ }^{\text {"41 }}$. Chęć przebywania w czystym środowisku, oddychania nie skażonym powietrzem, picia czystej wody, jest wyrazem postrzegania elementów biosfery jako dobra wspólnego. Jednostki przenoszą jednocześnie te pragnienia na poziom społeczności przy konstatacji braku osobistych, indywidualnych możliwości wywierania wpływu na osiągnięcie pożądanego stanu środowiska naturalnego. Społeczeństwo ma zatem naturalne prawo domagania się od jednostek zachowań realizujących ideał zachowania dobra wspólnego, jak i też samo jest adresatem postulatów jednostek.

Należy wrócić do zasygnalizowanego wcześniej pojęcia jakości życia ludzkiego jako przedmiotu kryterium relacji człowieka do środowiska naturalnego. Bardzo często jako uzasadnienie podejmowania przez władze publiczne określonych działań w zakresie ochrony środowiska, w tym w szczególności realizowania inwestycji, w wyniku których powstaje lub zostaje zmodernizowana infrastruktura techniczna służąca np. uzdatnianiu i dostarczaniu wody pitnej, czy też utylizacji odpadów, podawany jest argument konieczności poprawy jakości życia $^{42}$. Bardzo wyraźnie aspekt ten jest eksponowany w założeniach programowych polskiej polityki ekologicznej, która podkreśla, że nadrzędną wartością w polityce ekologicznej państwa jest człowiek. Oznacza to, że zdrowie społeczeństwa jako całości, komfort środowiska, w którym żyją i pracują społeczności lokalne oraz życie i zdrowie każdego obywatela są głównym, niepodważalnym kryterium w realizacji polityki ekologicznej na każdym szczeblu: w miejscu pracy i zamieszkania, na szczeblu lokalnym, regionalnym i krajowym. Obywatel ma zatem prawo domagać się, ażeby władza publiczna w swoich działaniach na rzecz bezpieczeństwa ekologicznego realizowała ideały tzw. dobrej administracji43. W tym kontekście trzeba zatem zastanowić się, co wyznacza obecnie poziom i standardy jakości życia? Czy zaspokajanie potrzeb ekologicznych ${ }^{44}$ (rozumia-

${ }_{41}$ Zob.: S.Kasprzak, Normatywny..., op.cit. s. 57.

42 Zobacz na ten temat M. RudNicki, Odpowiedzialność władz publicznych za realizację zadań $w$ dziedzinie ochrony środowiska, [w:] Prawość $i$ Godność, Księga pamiątkowa w 70 rocznicę urodzin Profesora Wojciecha Łaczkowskiego, Lublin 2003, s. 207 i n.

${ }_{43}$ Zob. na ten temat Z. NiEwIADOMsKi, Prawo do dobrej administracji-aspekty procesowe, ustrojowe i materialne, Biuletyn Biura Informacji Rady Europy, Nr 4/2003, s. 42 oraz A.Zoll, Dobra administracja jako prawo obywatela, Biuletyn Biura Informacji Rady Europy, $\mathrm{Nr} 4 / 2003$, s. 9.

${ }^{44}$ Por. S. Kasprzak, Normatywny..., s. 57. 
nych zbiorczo jako chęć życia w nieskażonym środowisku naturalnym i korzystania z zasobów naturalnych) jest naturalnym, pożądanym elementem właściwej jakości życia?

Współczesne pojmowanie jakości życia jest uwarunkowane zdywersyfikowanym poziomem życia poszczególnych społeczeństw Intuicyjnie można przyporządkować pojęcie „jakości życia” społeczeństwom rozwiniętym i zamożnym, gdyż zawiera ono w swej treści nie tylko poczucie materialnych podstaw egzystencji, ale także potrzebę zaspokajania egzystencjalnych potrzeb wyższego rzędu, np. dobrze zorganizowanej opieki zdrowotnej lub systemu edukacyjnego, czy też życia w czystym środowisku naturalnym. Pojęcie ,jakości życia” w społeczeństwach biednych, rozwijających się, nie zawiera w swej istocie dążenia do zaspokajania egzystencjalnych potrzeb wyższego rzędu, ale jest tożsame z pojęciem „przeżycia” lub "godnego życia”. Dlatego też omawiane pojęcie nie jest łatwe do jednoznacznego zdefiniowania. Bardzo trudno jest nie przyznać racji tym, którzy z pesymizmem i niewiarą w solidaryzm społeczności globalnej twierdzą, że potrzeby ekologiczne rozbudzone są w społeczeństwach bogatych i rozwiniętych i tam właśnie stanowią istotny element pożądanej jakości życia. Ponadto należy dostrzec różnicę w postrzeganiu potrzeb ekologicznych w społeczeństwie bogatym, świadomym stopnia degradacji środowiska naturalnego i mającym wysoko rozwiniętą ogólną świadomość ekologiczną, a postrzeganiem tych potrzeb w społeczeństwie biednym, nie świadomym zagrożeń ekologicznych i degradacji otaczającego je środowiska. W związku z tym należy zwrócić uwagę na problem sprawiedliwego udziału społeczeństw w przestrzeni ekologicznej ${ }^{45}$.

Stan środowiska naturalnego bardzo mocno oddziałuje na zaspokajanie egzystencjalnych potrzeb czlowieka i jest związany z potrzebami ekologicznymi, które można scharakteryzować jako wymagania odnoszące się do biologicznych, fizycznych, chemicznych i technologicznych właściwości poszczególnych elementów środowiska naturalnego. Człowiek dążąc do uzyskania zadawalającego go poziomu życia i odpowiedniej jego jakości dokonuje wyboru pomiędzy różnymi dobrami. Niestety, dobra ekologiczne bardzo często są traktowane jako dobra, które zajmują ostatnie miejsce w hierarchii i muszą ustępować np. dobrobytowi materialnemu, czy też bezpieczeństwu socjalnemu. Traktowanie dóbr ekologicznych jako dóbr ostatniej kategorii zaspokajania, często w sposób niezauważalny w krótkim okresie, prowadzi do trwałych i negatywnych zmian w bezpośrednim środowisku życia człowieka oraz wpływa ujemnie na jego stan zdrowia. Trafnie zauważa S. Kasprzak, że „deprawacja potrzeb ekologicznych, czyli swoistego rodzaju zwyrodnienie oczekiwań i zamiarów człowieka, prowadzi bardzo często do czasowej lub trwałej utraty zdrowia, a nawet życia" ${ }^{\prime \prime 6}$.

\footnotetext{
45 Zob. szerzej M. Carley, P. Spapens, Dzielenie się światem. Zrównoważonysposób życia i globalnie sprawiedliwy dostępdo zasobów naturalnych w XXI wieku, Białystok - Warszawa 2000, s.85 i n.

46 Ibidem, op. cit. s 55.
} 
Dlatego też niezwykle istotnym warunkiem wyboru i realizacji potrzeb ekologicznych jako potrzeb należących do pierwszorzędnych potrzeb egzystencjalnych mających istotny wpływ na jakość życia jest świadomość ekologiczna. Celem rozwoju świadomości ekologicznej człowieka jest wykształcenie takich zachowań, które byłyby nastawione na ochronę środowiska zarówno w wymiarze jednostkowym, jak i też w wymiarze ogólnym, dotyczącym całego społeczeństwa, jak i też poszczególnych jego grup, np. konsumentów lub przedsiębiorców. Kształtowanie się świadomości ekologicznej i zachowań proekologicznych w poszczególnych społeczeństwach zależne jest od ogólnego rozwoju kulturalnego i społecznego i gospodarczego ${ }^{47}$. We współczesnych, wysoko rozwiniętych społeczeństwach istnieją znaczne niewykorzystane potencjały, które poprzez prawidłowo realizowaną edukację ekologiczną i politykę informacyjną przyczynić się mogą do rozwoju właściwych, proekologicznych wzorców zachowań społecznych, konsumenckich, działań gospodarczych i dobrych praktyk produkcyjnych. Wysoko rozwinięta świadomość ekologiczna oraz pozytywne i przyjazne dla środowiska naturalnego postawy, zachowania i działania, będące istotnymi podstawami zrównoważonego rozwoju, wymagają dobrze zaplanowanego i konsekwentnie realizowanego kształcenia obejmującego różnorodne dziedziny ochrony środowiska. Organizatorami systemu kształcenia muszą być zarówno instytucje publiczne i prywatne, jak i też organizacje pozarządowe ${ }^{48}$. Kształcenie musi być uzupełniane o dobrze zorganizowaną politykę informacji o środowisku naturalnym i o jego stanie. Tylko takie kompleksowe działania mogą służyć rozwojowi i upowszechnianiu trwałych, proekologicznych wzorców zachowań i postaw polityków, przedsiębiorców, konsumentów i ogółu społeczeństwa. Kształcenie, informowanie i wiedza na temat środowiska naturalnego znajdują swoje oparcie w konwencji z Aarhus ${ }^{49}$, dotyczącej dostępu do informacji, udziału społeczeństwa i opinii publicznej w procesach decyzyjnych i dostępie do wymiaru sprawiedliwości w dziedzinie środowiska.

47 Zob. L.MöLler, Proekologiczna edukacja oraz informacja o środowisku jako główne składniki świadomości ekologicznej, [w:] Międzynarodowe zarządzanie środowiskiem. Tom I, Interdyscyplinarne założenia proekologicznego zarządzania przedsiębiorstwem. Studia Ekonomiczne, M.Kramer, M.Urbaniec, A.Kryński (red.), (rec. nauk. - K.Biernat, M.Rudnicki), Warszawa 2004, s. 133 i n.

48 Zob. uwagi krytyczne dotyczące kształcenia w dziedzinie ochrony środowiska R. PACzuskI, O niedostatku nauczania prawa ochrony środowiska w Polsce, [w:] Zasada zrównoważonego rozwoju w prawie i praktyce ochrony środowiska, K.Równy, J.Jabłoński (red.), Warszawa 2002, s.293 in.

${ }^{49}$ Zob. Konwencja o dostępie do informacji, udziale społeczeństwa w podejmowaniu decyzji oraz dostępie do sprawiedliwości w sprawach dotyczących środowiska, sporządzona dnia 25 czerwca 1998 roku w Aarhus w Danii, ratyfikowana przez Polskę w dniu 21 czerwca 2001 r. (ustawa $\mathrm{z}$ dnia 21 czerwca 2001 r. o ratyfikacji Konwencji o dostępie do informacji, udziale społeczeństwa w podejmowaniu decyzji oraz dostępie do sprawiedliwości w sprawach dotyczących środowiska (Dz. U. z 2001 r. Nr 89, poz. 970). 
Każda działalność człowieka w środowisku naturalnym pociąga za sobą określone jego przemiany, których charakter uzależniony jest od rodzaju ludzkiej aktywności, jej intensywności i zgodności z obowiązującymi normami. Problem ingerencji człowieka $\mathrm{w}$ środowisko naturalne związany jest $\mathrm{z}$ zasadniczym sporem dotyczącym określenia priorytetów rozwoju cywilizacyjnego, w szczególności w dobie, kiedy postęp realizowany rzekomo w imię dobra człowieka, zaczął bezpośrednio zagrażać jego zdrowiu i życiu ${ }^{50}$. Jednym $z$ ważniejszych problemów środowiskowych i cywilizacyjnych jest to, że współcześnie rozwój gospodarczy i postęp naukowo-techniczny są ściśle od siebie zależne i wzajemnie na siebie oddziałują. Realizując program rozwoju gospodarczego przy użyciu dostępnej techniki i technologii dochodzi często do nadmiernej eksploatacji środowiska naturalnego ${ }^{51}$. W wyniku tej eksploatacji człowiek otrzymuje podstawowe surowce produkcyjne i równocześnie przyczynia się do powstania szeregu zanieczyszczeń środowiska. Struktura tych zanieczyszczeń powstających w wyniku działalności eksploatacyjnej i produkcyjnej jest wynikiem zarówno działalności gospodarczej jak i poziomu technologicznego w poszczególnych dziedzinach działalności ${ }^{52}$.

Oprócz aspektów gospodarczych, na kształt środowiska naturalnego wpływ mają także sprawy społeczne. Szczególne zwrócenie uwagi na aspekt relacji społecznych w odniesieniu do środowiska naturalnego jest uzasadnione tym, że trwałe przekształcenia w środowisku naturalnym powodują także zmianę stosunku społeczeństwa do natury. Wynika z tego, zdaniem K.Górki wniosek, że współdziałanie społeczeństwa i natury musi być badane nie tylko w układzie statycznym, lecz także dynamicznym, umożliwiającym poznanie zarówno samej istoty tego działania jak i kierunku jego ewolucji53.

Czy rozwój ten ma być podporządkowany gospodarce, czy też osią tego rozwoju ma być ochrona i zachowanie zasobów środowiska naturalnego? Czy może najrozsądniejsze jest zrównoważenie celów gospodarczych, społecznych i ekologicznych ${ }^{54}$ Tak stawiany problem świadczy o jego znaczeniu w życiu globalnej społeczności i od lat skłania do przemyśleń i refleksji ${ }^{55}$.

50 Zob. Z. Karaczun, L. Ludeka, Ochrona środowiska, Warszawa 1996, s. 263.

${ }^{51}$ Zob. szerzej na temat racjonalności zużycia zasobów naturalnych i koncepcji tzw. „mnożnika cztery" jako relacji pomiędzy zwiększaniem dobrobytu a ograniczaniem zużycia zasobów środowiska naturalnego: E.U.von Weizsacker, A.B. Lovins, L. Hunter Lovins, Mnożnik cztery, podwojony dobrobyt - dwukrotnie mniejsze zuzycie zasobów naturalnych, Torun 1999.

52 Zob. A. Ciborowski, Polityka kształtowania środowiska, Warszawa 1981, s. 80 - 82 oraz G. Dobrzański, B.Dobrzańska, D.Kiełczewski, E.Łapińska,, Ochrona środowiska przyrodniczego, Białystok 1998, s. 131 - 132.

53 Zob. K. Górka, B. Posкrobko, W. Radecki, Ochrona środowiska. Problemy spoleczne, ekonomiczne i prawne, Warszawa 1998, s. 16-20.

54 Zob.np. T. ŻYLICZ, Ekonomia wobec problemów środowiska przyrodniczego, Warszawa 1990.

55 Zob.np. S. CZAJA, B. FIEDOR, Z. JAKUBCZYK, Ekologiczne uwarunkowania wzrostu gospodarczego w ujęciu współczesnej teorii ekonomii, Białystok - Kraków 1992. 
Jak podkreśla W.Michajłow, kluczową sprawą jest dokładne określenie przyczyn i skutków, a także dalszych następstw przemian zachodzących w środowisku w wyniku działalności społecznej i gospodarczej człowieka. Dokonane oceny powinny służyć do określenia skutecznych sposobów zapobiegania, bądź ograniczenia ujemnych następstw dla środowiska, a przede wszystkim dla człowieka ${ }^{56}$. Jak trudno jest rozwiązywać te dylematy w skali globalnej świadczy chociażby to, że międzynarodowe porozumienia służące ochronie środowiska są podpisywane jedynie $\mathrm{w}$ tych dziedzinach, które są $\mathrm{w}$ pełni zgodne $\mathrm{z}$ narodowymi interesami poszczególnych państw ${ }^{57}$.

Dlatego w poszukiwaniu kompromisu pomiędzy gospodarką a środowiskiem naturalnym należy opierać się na wielowątkowej analizie problemu, uwzględniającej zarówno podstawowe prawa przyrodnicze, jak i też społeczne i ekonomiczne ${ }^{58}$.

Człowiek wraz ze swoją działalnością jest ściśle sprzężony z systemem przyrodniczym. Zachowanie równowagi w tym systemie wymaga spójnego i łącznego zarządzania zarówno dostępem do zasobów środowiska oraz likwidacją i zapobieganiem powstawaniu negatywnych dla środowiska skutków działalności gospodarczej (ochrona środowiska), jak i racjonalnym użytkowaniem zasobów przyrodniczych (gospodarka wodna, leśnictwo, ochrona i wykorzystanie zasobów surowcowych i glebowych, planowanie przestrzenne). Powinno to znaleźć odbicie w odpowiednich strukturach zarządzania na szczeblu krajowym, regionalnym i lokalnym oraz takim podziale kompetencji, zadań i dostępnych procedur, aby cele polityki ekologicznej na każdym szczeblu były wyznaczane w oparciu o prawidłowe rozpoznanie potrzeb, zaś środki do ich osiągnięcia były dobierane przede wszystkim w oparciu o kryteria efektywności ekologicznej i ekonomicznej. Tylko w takim przypadku można mówić o zapewnieniu obywatelom bezpieczeństwa ekologicznego i realizacji zasady zrównoważonego rozwoju w formule kompromisu ekologii z ekonomią.

56 Zob. E. Ha£oń, W. MichajŁow, Czlowiek iśrodowisko, Wroclaw 1979, s. 113-114.

7 Zob. A. Budnikowski, Ochrona środowiska jako problem globalny, Warszawa 1998, s. 156-159.

58 Zob. J. Machowski, Ochrona środowiska. Prawo i zrównoważony rozwój, Warszawa 2003, s. 65-66. 


\section{Balanced development as a basis of polish ecological politics, in searching of the new formula of the compromise between ecology and economy}

\section{SUMMARY}

The article includes detailed analysises of basic terms and concepts, especially the phrases: balanced development, ecological politics, compromise, ecology, economy. These analysises show the rich context of international science researches, European Union, Poland and they present wide historical and contemporary aspect
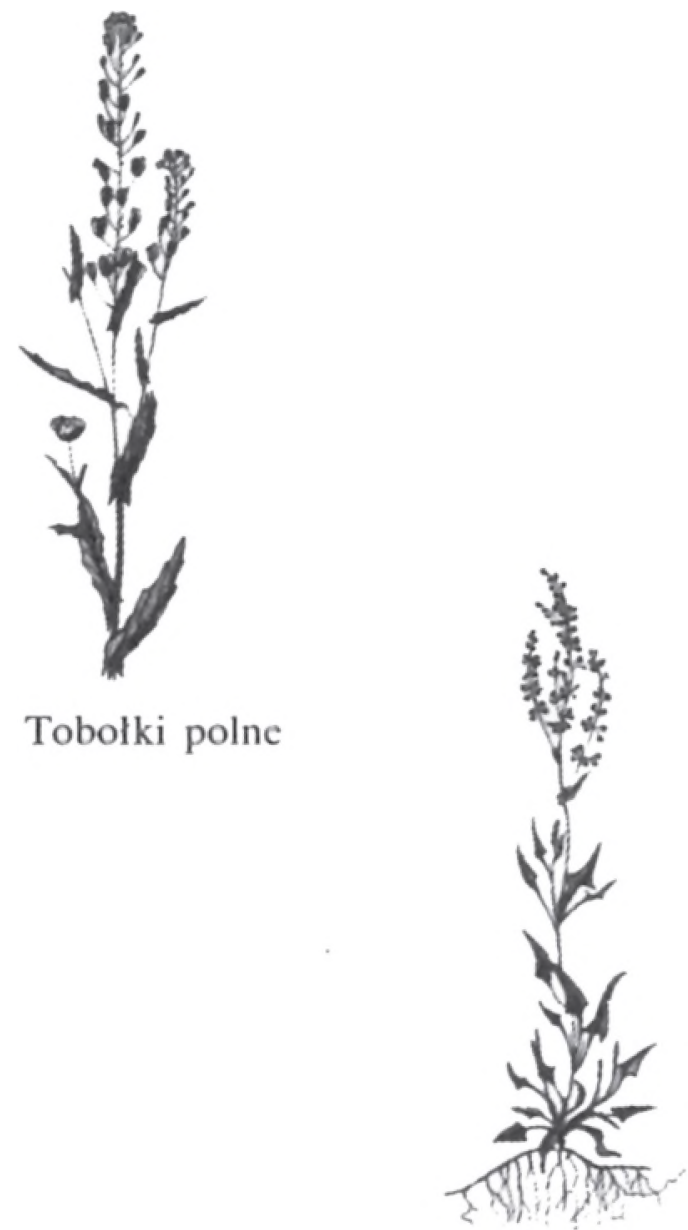

Szczaw polny 